\title{
Effect of Highly Active Antiretroviral Therapy on Incidence of Opportunistic Infections among HIV Positive Adults in Public Health Facilities of Arba Minch Town, South Ethiopia: Retrospective Cohort Study
}

\section{DiresIgne Misker ${ }^{1 *}$, Meaza Demissie ${ }^{2}$ and Habtamu Mellie ${ }^{3}$}

${ }^{1}$ Arba Minch University, Department of Public Health, Arba Minch, Ethiopia

${ }^{2}$ Debre Markos University, Department of Public Health, Debre Markos, Ethiopia

${ }^{3} \mathrm{ACIPH}$, Addis Ababa, Ethiopia

\begin{abstract}
Background: Studies of Antiretroviral Therapy program in Africa have shown high incidence rate of opportunistic infections in both Antiretroviral Therapy receiving and Pre ART Human Immunodeficiency Virus infected patients. However, incidence of opportunistic infections and factors that contribute for development of it were poorly described in Ethiopia especially in the study area.
\end{abstract}

Objective: To determine the effect of HAART on incidence rate of opportunistic infections among HIV-positive adults in Public Health facilities of Arba Minch town.

Method: Retrospective cohort study was used and the required sample size was 464 . Study participants were selected randomly from the list of adult people living with HIV attending the public health facilities for ART. Univariate analysis was used to describe patients' baseline and follow up characteristics. Kaplan-Meier survival and log rank test were used to estimate survival and compare survival curves respectively. Cox proportional-hazard regression model was used to determine independent predictors of incidence of opportunistic infections.

Result: A total of 464 patients ( 232 in each cohort) contribute for 898.12 person years of follow up. The incidence of opportunistic infections was 55.8 per 100 person year and 3.4 per 100 person year of follow up in pre ART and HAART cohorts respectively. Being on HAART decreased occurrence of opportunistic infections by $93 \%$. In contrary being male, being widowed, substance use, rural residence and having baseline CD4 count of 350-499 cells/ $\mu \mathrm{l}$ are independent predictors of increased risk of opportunistic infections.

Conclusion: The incidence of opportunistic infection was higher in pre ART cohort. Male gender, being widowed, substance use, rural residence and having baseline CD4 count of 350-499 cells/ $\mu$ l were independent predictors of increased risk of opportunistic infections.

Keyword: Incidence; Opportunistic infection; HIV; Arba Minch

\section{Introduction}

According to the latest United Nation's Agency for International Development (UNAID) estimate, about 34 million people were living with human immunodeficiency virus (HIV) in 2011 [1,2]. Globally, the annual number of people dying from acquired immunodeficiency syndrome (AIDS)-related causes was 1.7 million in 2011 [3]

According to 2011 Ethiopian demographic health survey, the overall national adult (age 15-49 years) HIV prevalence was 1.5\% (1\% among males and $1.9 \%$ among females) and $0.9 \%$ for SNNPR [4]. Introduction of combination antiretroviral therapy in 1996 has led to dramatic reductions in morbidity and mortality from HIV/AIDS [1,2]. In Ethiopia, the fee based and universal free access antiretroviral (ARV) treatment was started in 2002/3 and 2004/5 respectively [5,6].

Ethiopia has been engaged in the scale-up of ART access to its people since 2005. Despite challenges like poor health infrastructure, lack of state of the ART diagnostic tools, and shortage of health care providers, ART scale- up has recorded the greatest achievement in the number of people reached and facilities providing these services over the last few years. The number of sites providing the ART service had increased from 3 to 874 and people started on treatment increased from 24,000 to 308,000 from 2006 to 2012 [7].

Opportunistic infections (OIs) are diseases that rarely occur in healthy people but cause infections in individuals whose immune systems are compromised, including by HIV infection. Organisms that cause OIs are frequently present in the body but are generally kept under control by a healthy immune system. HIV gradually weakens a person's immune system and leads to the development of one or more opportunistic infections, which signals the progression to AIDS. These illnesses are generally the eventual cause of death due to HIV infection [8].

OIs can occur in about $40 \%$ of people living with HIV (PLHIV) with a CD4 count less than $250 / \mathrm{mm}^{3}$ [9]. About $39.1 \%$ of the patients already had an opportunistic infection, which was the first manifestation of immune suppression caused by HIV. Of the total of opportunistic infections, $74.2 \%$ occurred in the non-HAART group, in the HAART group there were $25.8 \%$ episodes of opportunistic infections recorded, $83.6 \%$ of who were using the first regimen of combined therapy [10].

*Corresponding author: Direslgne Misker, Arba Minch University, Department of Public Health, Arba Minch, Ethiopia, Tel: +251-920-27-44-02; E-maildiresmisker@gmail.com

Received June 03, 2014; Accepted July 30, 2014; Published August 07, 2014

Citation: Misker D, Demissie M, Mellie H (2014) Effect of Highly Active Antiretrovira Therapy on Incidence of Opportunistic Infections among HIV Positive Adults in Public Health Facilities of Arba Minch Town, South Ethiopia: Retrospective Cohort Study. J AIDS Clin Res 5: 330. doi:10.4172/2155-6113.1000330

Copyright: (C) 2014 Misker D, et al. This is an open-access article distributed unde the terms of the Creative Commons Attribution License, which permits unrestricted use, distribution, and reproduction in any medium, provided the original author and source are credited. 
Citation: Misker D, Demissie M, Mellie H (2014) Effect of Highly Active Antiretroviral Therapy on Incidence of Opportunistic Infections among HIV Positive Adults in Public Health Facilities of Arba Minch Town, South Ethiopia: Retrospective Cohort Study. J AIDS Clin Res 5: 330. doi:10.4172/2155-6113.1000330

Page 2 of 6

OIs are major causes of morbidity and mortality among PLWHIV but little is known about the incidence of these infections. So this study is aimed at assessing the incidence of OIs in PLWHIV.

\section{Methods and Materials}

\section{Study setting and study design}

Arba Minch town has one Zonal hospital and one public health center, which provide ART service. There are 4759 adult PLWHIV in Arba Minch Hospital and Health center on chronic HIV care of these 2143 were between November 27, 2009 and January 24, 2014. Retrospective cohort study design was used.

\section{Source and study population}

All PLWHIV registered in public Health facilities of Arba Minch town were the source populations. All PLWHIV registered in public Health facilities of Arba Minch town from November 27, 2009 to January 24, 2014 were the study populations

\section{Sample size determination}

The sample size was calculated based on the assumption of $95 \%$ confidence interval and $80 \%$ power for two population proportion formula with one to one ratio for HAART and pre- ART PLWHIV using the proportions of OIs,74.2\% for Pre ART and $25.8 \%$ HAART PLHIV respectively [10]. Epi info version 3.5 .1 is used to calculate the sample size.

$$
n_{1}=\frac{\left[Z_{\frac{\alpha}{2}} \sqrt{\left(1+\frac{1}{r}\right) P(1-P)}+Z_{\beta} \sqrt{P_{1}\left(1-P_{1}\right)+\frac{P_{2}\left(1-P_{2}\right)}{r}}\right]^{2}}{\left(P_{1}-P_{2}\right)^{2}}
$$

Where:

$$
r=\frac{n_{2}}{n_{1}} \quad P=\frac{P_{1}+r P_{2}}{1+r}
$$

$\mathrm{n}_{1}=$ number of HIV infected patients who are Pre ART (non exposed)

$\mathrm{n}_{2}=$ number of HIV infected patients who are on ART (Exposed)

$r=$ the ratio of exposed to non exposed HIV infected patients $=1$

$\mathrm{P}_{1}=$ proportion of OIs in HAART receiving HIV infected patients

$\mathrm{P}_{2}=$ proportion of OIs in Pre ART HIV infected patients

$\mathrm{Z}_{\alpha / 2}: 1.96$ at $95 \%$ confidence interval

Accordingly, the calculated sample size was 422 (211 for HAART and Pre ART); after adding $10 \%$ contingency the total sample size was 464, 232 patients for each cohort (Figure 1).

\section{Data collection and quality control}

Data collection format was developed from federal ministry of health HIV care/ART follow up form which is used in the ART clinic and also the patients' card; the format includes the following check list:

- socio-demographic characteristics (sex, age, residence, marital status, occupational status, educational status);

- ART and chemoprophylaxis information (ARV drug treatment, drug adherence, line of treatment regimen, prophylaxis treatment and its adherence);

- laboratory information (CD4 count, hemoglobin value);

- Clinical information (WHO clinical staging, weight, height); and

- Functional status of patients (working, ambulatory, bedridden).

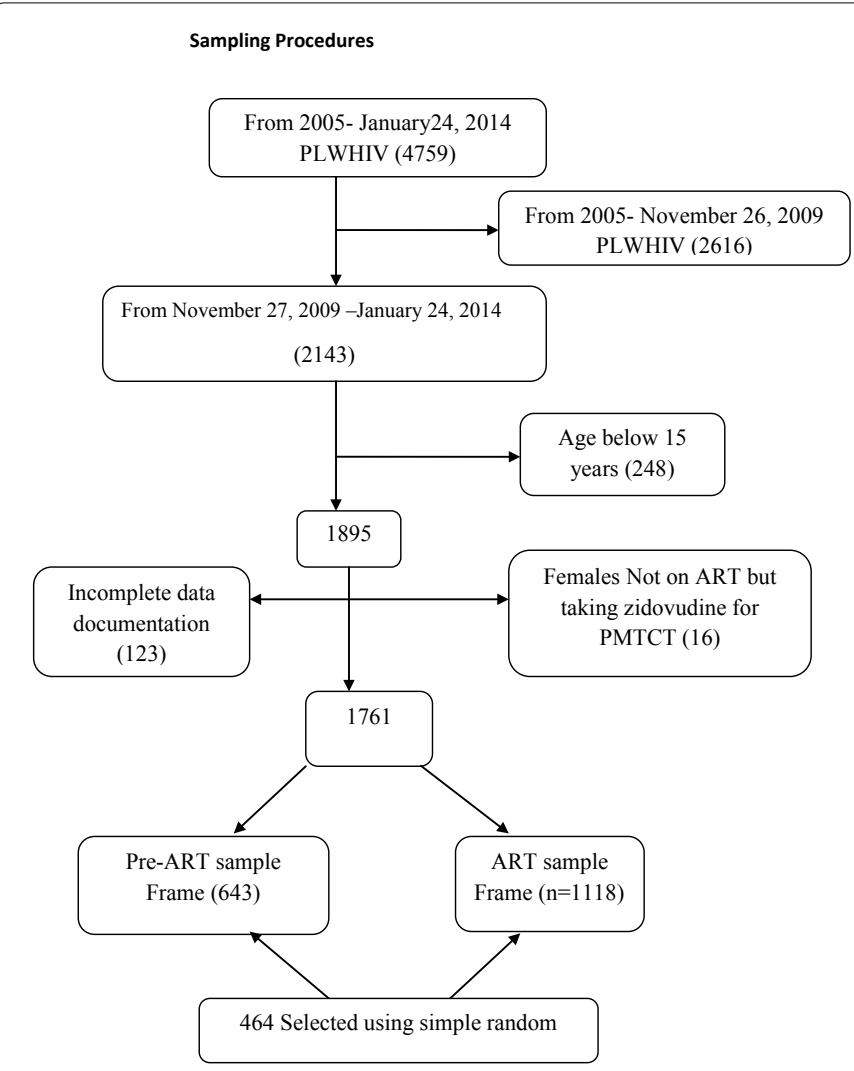

Figure 1: Schematic presentation of sampling procedure of PLWHIV enrolled for cohort between $27^{\text {th }}$ November, 2009 and 24 $4^{\text {th }}$ January, 2014 in public Health facilities of Arba Minch town, Southern Ethiopia, 2014.

The data was collected by reviewing HIV care/ART follow up form, laboratory requests and patients' card. To ensure the quality of data, data collectors are trained nurses, recruited from ART clinic on method of extracting the needed data from patient's records and filling on data collection format. On the days of data collection, the principal investigator and the supervisor supervises the data collection process by checking completeness of the data. Three data collectors and one supervisor who had direct experience and working on ART clinic was recruited for data collection and supervision respectively. Data collectors and supervisor was trained on objectives of the study, selection of exposed and unexposed, how to keep confidentiality of information, the contents of the questionnaire and data quality management by the principal investigator. Individuals who drop-out, loss to follow-up, transferred out, dead by any disease other than OI where cause of death not confirmed during study period or not develop any OI at the end of the study period was considered as censored.

\section{Data processing and analysis}

The data collection form was checked for completeness and consistency by the principal investigator before data entry. Completed data abstraction form was coded by numbers and entered in computer software EPI info version 3.5.1 statistical package and exported to SPSS version 16 and STATA version 11 for analysis. The risk of developing OIs among patients with retrospective follow up in Pre ART or HAART cohort was assessed using the person-year method. Incidence rate was calculated as number of OIs cases per 100 person year observed. Cox proportional hazards model was used to assess predictors of incidence of OIs, the Kaplan-Meier technique and the generalized log-rank test 
Citation: Misker D, Demissie M, Mellie H (2014) Effect of Highly Active Antiretroviral Therapy on Incidence of Opportunistic Infections among HIV Positive Adults in Public Health Facilities of Arba Minch Town, South Ethiopia: Retrospective Cohort Study. J AIDS Clin Res 5: 330. doi:10.4172/2155-6113.1000330

Page 3 of 6

were used to construct and compare the OIs-free survival probabilities curves of the two groups.

\section{Study variables}

\section{Dependent variable}

- Occurrence of OIs

\section{Independent variable}

- Exposure variable: HAART status (HAART initiation or not)

- Socio demographic (Age, sex, education status, marital status, occupation status)

- Clinical and other variables ( weight, CD4+ count, prophylaxis (IPT and CPT), Hemoglobin level, adherence level for HAART, WHO clinical stage at baseline)

\section{Operational Definition}

Opportunistic infection: PLWHIV who develops either Herpes zoster, candidacies (oral or vaginal), Creptoccocal Meningitis, Chronic Diarrhea, encephalopathy, herpes simplex, PCP, pneumonia, PTB, EPTB, intestinal parasitosis, Toxoplasmosis, upper respiratory tract infection is considered as having OIs.

Pre ART PLWHIV: The person whose HIV positive status confirmed but not eligible for ART;

HAART PLWHIV: The person whose HIV positive status confirmed and started ART;

Survival: The person without any OI occurrence

Censored: Non-occurrence of any OI in study participant during follow-up study but not sure for future occurrence;

Drop out: If a PLWHIV on HIV care lost to follow up for more than three months as recorded by ART clinic personnel;

Lost to follow up: If PLWHIV on HIV care not seen for equal to or more than one month as recorded by ART clinic personnel;

Transferred out: If PLWHIV on HIV care in one health institution shift to other health institution;

\section{Ethical considerations}

Ethical clearance was obtained from the Ethical Review Committee (ERC) of ACIPH before conducting the study. After securing ethical clearance from ERC ACIPH, Arba Minch Hospital and Health center was informed about the objective of the study and written consent was obtained. To keep the confidentiality of the patients, data collectors was recruited from ART clinic and personal identifiers were not included in the data abstraction format and the information collected for this research kept confidential.

\section{Result}

\section{Socio-demographic characteristics of the study subjects}

Majority of the participants (64\%) are female and 79\% are urban residence. More than one third (38.1\%) of the patients were in the age range between 25 and 34 years with median age $( \pm$ SD) of $30( \pm 9.8)$. (Table 1)

\section{Baseline and follow up characteristics of HIV infected patients in Arba Minch town, 2014}

In this retrospective cohort study there were 177(38.2\%) OI cases,
31(6.7\%) lost to follow up/drop out, 22(4.7\%) transfers out, 9(1.9) deaths and 225(48.5\%) HIV positive people didn't develop OI up to the end of the study. 197 (85\%) have good adherence to drugs, 196 (42.2\%) were not taking any prophylaxis, 171(73.7\%) started HAART when they fulfill CD4 count criteria only. Concerning the type of HAART the patient takes all took first line HAART and at baseline around $40.9 \%$ of patients were taking Tenofevir, Lamivudine and Efaverenz combination while around $20 \%$ were taking Stavudine, Lamivudine and Nevirapine and there rest took other combinations (Table 2).

\section{Comparison of OIs incidence rate and OIs free survival in Pre ART and HAART cohorts}

All the 464 study subjects have contributed for their respective group OI free time follow up observation 279.39 PY and 618.73 PY in Pre-ART and HAART cohort respectively. In Pre-ART cohort more HIV infected patients developed OI (156) than ART cohort [11] with the incidence rate of 55.8 per $100 \mathrm{PY}$ and 3.4 per $100 \mathrm{PY}$ respectively. Overall probability of not developing OIs in the HAART cohort was significantly greater than that of the Pre-ART cohort, i.e. the risk of developing OIs is higher in Pre-HAART group $(\mathrm{P}<0.001)$ (Figure 2$)$.

In HAART cohort, from those who developed OI, around $57 \%$ of OI cases occur in the first two years of follow up but in the Pre ART $56.4 \%$ of the OI cases occurred in the first one year. Based on the life table analysis the probability of not developing OI at one, two, three and four year in HAART cohort were $96 \%, 94 \%, 90 \%$ and $88 \%$ respectively. The corresponding values in Pre-ART cohort were 58\%, $41 \%, 24 \%$, and $8 \%$ respectively. This clearly showed that the probability of not developing OI at the end of study period in Pre-ART cohort was lower than that of HAART cohort (0\% Vs $82 \%$ respectively) (Table 3 ).

\section{Predictors of OIs incidence}

Before fitting the covariate into the model all the proportional hazard assumptions were checked by Schoenfeld residual and by examining log minus log plots. To identify independent predictors of developing OI, a multivariate Cox-Proportional hazard adjusted model

\begin{tabular}{|l|c|c|c|}
\hline \multicolumn{1}{|c|}{ Characteristic } & ART No (\%) & Pre ART No (\%) & Total No (\%) \\
\hline Sex & & & \\
Male & $68(29.3)$ & $99(42.7)$ & $167(36)$ \\
Female & $164(70.7)$ & $133(57.3)$ & $297(64)$ \\
\hline Age category & & & \\
$15-24$ & $22(9.5)$ & $99(42.7)$ & $121(26.1)$ \\
$25-34$ & $99(42.7)$ & $78(33.6)$ & $177(38.1)$ \\
$35-44$ & $72(31)$ & $49(21.1)$ & $121(26.1)$ \\
>=45 & $39(16.8)$ & $6(2.6)$ & $45(9.7)$ \\
\hline Marital status & & & \\
Married & $119(51.3)$ & $126(54.3)$ & $245(52.8)$ \\
Single & $25(10.8)$ & $63(27.2)$ & $88(19)$ \\
Divorced & $35(15.1)$ & $16(6.9)$ & $51(11)$ \\
Widowed & $53(22.8)$ & $27(11.6)$ & $80(17.2)$ \\
\hline Residence & & & \\
Urban & $200(86.2)$ & $165(71.1)$ & $365(78.7)$ \\
Rural & $32(13.8)$ & $67(28.9)$ & $99(21.3)$ \\
\hline Employment status & & & \\
Employed & $167(72)$ & $126(54.3)$ & $293(63.1)$ \\
Unemployed & $65(28)$ & $106(45.7)$ & $171(36.9)$ \\
\hline Educational status & & & \\
No education & $80(34.5)$ & $64(27.6)$ & $144(31)$ \\
Primary & $83(35.8)$ & $80(34.5)$ & $163(35.1)$ \\
Secondary & $56(24.1)$ & $71(30.6)$ & $127(27.4)$ \\
\hline Tertiary & $13(5.6)$ & $17(7.3)$ & $30(6.5)$ \\
\hline Table 1: Socio & & & \\
\hline
\end{tabular}

Table 1: Socio Demographic characteristics of respondents in public Health facilities of Arba Minch town, January, 2014. 
Citation: Misker D, Demissie M, Mellie H (2014) Effect of Highly Active Antiretroviral Therapy on Incidence of Opportunistic Infections among HIV Positive Adults in Public Health Facilities of Arba Minch Town, South Ethiopia: Retrospective Cohort Study. J AIDS Clin Res 5: 330. doi:10.4172/2155-6113.1000330

\begin{tabular}{|c|c|c|c|}
\hline Characteristics & Pre ART No (\%) & HAART No (\%) & Total No (\%) \\
\hline $\begin{array}{l}\text { Functional Status B } \\
\text { Working } \\
\text { Ambulatory \& Bedridden }\end{array}$ & $\begin{array}{c}223(96.1) \\
9(3.9)\end{array}$ & $\begin{array}{c}213(91.8) \\
19(8.2)\end{array}$ & $\begin{array}{c}436(94) \\
28(6)\end{array}$ \\
\hline $\begin{array}{l}\text { WHO Stage }{ }^{B} \\
\text { Stage I } \\
\text { Stage II } \\
\text { Stage III } \\
\text { Stage IV }\end{array}$ & $\begin{array}{c}181(78) \\
42(18.1) \\
9(3.9) \\
0(0)\end{array}$ & $\begin{array}{c}134(57.8) \\
32(13.8) \\
56(24.1) \\
10(4.3)\end{array}$ & $\begin{array}{c}315(67.9) \\
74(16) \\
65(14) \\
10(2.1)\end{array}$ \\
\hline $\begin{array}{l}\text { Hemoglobin level }{ }^{B} \\
<10 \mathrm{mg} / \mathrm{dl} \\
\geq 10 \mathrm{mg} / \mathrm{dl}\end{array}$ & $\begin{array}{c}12(5.2) \\
220(94.8)\end{array}$ & $\begin{array}{c}24(10.3) \\
208(89.7)\end{array}$ & $\begin{array}{c}36(7.8) \\
428(92.2)\end{array}$ \\
\hline $\begin{array}{l}\text { CD4+ Count }{ }^{B} \\
<200 \\
200-349 \\
350-499 \\
>=500\end{array}$ & $\begin{array}{c}0(0) \\
14(6) \\
93(40) \\
125(54)\end{array}$ & $\begin{array}{c}107(46.1) \\
116(50) \\
8(3.5) \\
1(0.4)\end{array}$ & $\begin{array}{c}107(23) \\
130(28) \\
101(21.8) \\
126(27.2)\end{array}$ \\
\hline $\begin{array}{l}\text { Substance use }{ }^{B} \\
\text { Yes } \\
\text { No }\end{array}$ & $\begin{array}{c}24(10.3) \\
208(89.7)\end{array}$ & $\begin{array}{c}58(25) \\
174(75)\end{array}$ & $\begin{array}{c}82(17.7) \\
382(82.3)\end{array}$ \\
\hline $\begin{array}{l}\text { Prophylaxis }{ }^{B} \\
\text { Yes } \\
\text { No }\end{array}$ & $\begin{array}{c}62(26.7) \\
170(73.3)\end{array}$ & $\begin{array}{c}206(88.8) \\
26(11.2)\end{array}$ & $\begin{array}{l}268(57.8) \\
196(42.2)\end{array}$ \\
\hline $\begin{array}{l}\text { CD4+ Count }{ }^{F} \\
<200 \\
200-349 \\
350-499 \\
>=500\end{array}$ & $\begin{array}{l}20(8.6) \\
62(26.7) \\
68(29.3) \\
82(35.4)\end{array}$ & $\begin{array}{c}13(5.6) \\
71(30.6) \\
76(32.8) \\
72(31)\end{array}$ & $\begin{array}{c}33(7.1) \\
133(28.7) \\
144(31) \\
154(33.2)\end{array}$ \\
\hline $\begin{array}{l}\text { Substance use }{ }^{F} \\
\text { Yes } \\
\text { No }\end{array}$ & $\begin{array}{c}25(10.8) \\
207(89.2)\end{array}$ & $\begin{array}{c}55(23.7) \\
177(76.3)\end{array}$ & $\begin{array}{c}70(17.2) \\
384(82.8)\end{array}$ \\
\hline $\begin{array}{l}\text { Prophylaxis }{ }^{F} \\
\text { Yes } \\
\text { No }\end{array}$ & $\begin{array}{c}95(40.9) \\
137(59.1)\end{array}$ & $\begin{array}{c}98(42.2) \\
134(57.8)\end{array}$ & $\begin{array}{l}193(41.6) \\
271(58.4)\end{array}$ \\
\hline $\begin{array}{l}\text { Functional Status } \mathrm{F} \\
\text { Working } \\
\text { Ambulatory \& Bedridden }\end{array}$ & $\begin{array}{c}186(90.2) \\
46(19.8)\end{array}$ & $\begin{array}{c}230(99.1) \\
2(0.9)\end{array}$ & $\begin{array}{c}466(89.7) \\
48(10.3)\end{array}$ \\
\hline
\end{tabular}

$\mathrm{F}=$ follow up, $\mathrm{B}=$ baseline

Table 2: Baseline and follow up characteristics of HIV infected patients in public Health facilities of Arba Minch town, 2014.

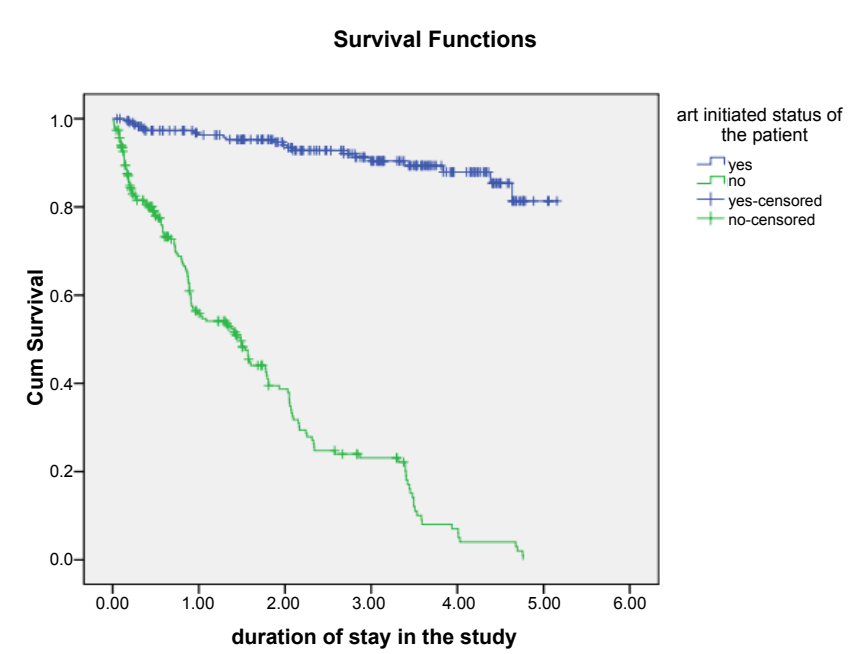

Figure 2: Kaplan-Meier estimate of $\mathrm{OI}$ free survival with and without ART, in public Health facilities of Arba Minch town, Ethiopia, 2014.

was fitted with the variables having a P-value less than 0.2 in the bivariate analysis. Multi-colinearity was checked using correlation estimates, and we found that follow up WHO stage was highly correlated with follow up $\mathrm{CD} 4$ count $(\mathrm{r}=0.56)$, so that further analysis in the final model was not done for follow up WHO stage. The risk of developing OI increased in males $(\mathrm{AHR}=2.19,95 \% \mathrm{CI}=1.55-3.11$ and $\mathrm{P}<0.001)$, in widowed marital status $(\mathrm{AHR}=1.68,95 \% \mathrm{CI}=1.08-2.60, \mathrm{P}=0.022)$, being rural residence $(\mathrm{AHR}=1.62,95 \% \mathrm{CI}=1.15-2.27, \mathrm{P}=0.005)$ compared with their counter parts.

Another important predictor of OI incidence was being on substance user or not. The risk of developing OI in individuals who was using substance at baseline and follow up is nearly two times higher than that of non user cohorts $(\mathrm{P}<0.001)$. Study subjects with baseline CD4 count between $350-499$ cells/ $\mu$ l is nearly two times higher than those with greater than or equal to 500 cells $/ \mu \mathrm{l}(\mathrm{p}=0.004)$ but baseline CD4 count of $<200$ cells $/ \mu \mathrm{l}$ and $200-349$ cells/ $\mu$ l is not associated with OI incidence with $p$ value of 0.792 and 0.694 respectively. Taking HAART is preventive of OIs occurrence $(\mathrm{AHR}=0.07,95 \% \mathrm{CI}=0.03$ $0.16, \mathrm{P}<0.001$ (Table 4).

\section{Discussion}

In this retrospective cohort study, $156(67.2 \%)$ of the participants had occurrence of OIs in the pre ART cohort and 21(9.1\%) in the HAART cohort. The overall incidence of OIs was 19.7 per $100 \mathrm{PY}$. The incidence of OIs showed a decline from 55.84/100 PY (95\% CI: 47.58, $65.13)$ in those patients not using HAART to $3.39 / 100$ PY (95\%CI: $2.157,5.1$ ) in those using HAART. Being widowed than married, male gender, substance use, rural residence and having baseline CD4 count of 350-499 cells/ $\mu$ and follow up CD4 count other than Above 500 cells/ $\mu \mathrm{l}$ were factors increased occurrence of OIs; however, the preventive factors were taking HAART and not being in the age range 15-24.

This study showed that, $156(67.2 \%)$ of the participants had occurrence of OIs in the pre ART cohort and 21(9.1\%) in the HAART cohort. This is in line with a study in Taiwan which said $8 \%$ of patients developed OI after HAART. However the proportion of OIs is lower than a study conducted in Brazil in which the proportion of OI in pre ART and HAART cohort was 74.2\%, 25.8\% respectively. This decrement may be due to the fact that the current study includes only adults but the previous study includes children who may have lower immunity than adults and may lead to increased proportion of OIs.

The overall incidence of OIs was 19.7 per 100 PY. It was higher compared to the results from South Africa 8.52/100 PY and lower from $\mathrm{Co}^{\wedge}$ te d'Ivoire $36.8 / \mathrm{PY}$. These could be explained as a result of the study in South Africa considers only severe HIV related illness so which might have underestimation of the overall morbidity density rate. The

\begin{tabular}{|l|c|c|c|c|c|c|}
\hline \multirow{4}{*}{ ART status } & $\begin{array}{c}\text { Interval } \\
\text { Start Time } \\
\text { in year }\end{array}$ & $\begin{array}{c}\text { Number } \\
\text { Entering } \\
\text { Interval }\end{array}$ & $\begin{array}{c}\text { Number } \\
\text { Withdrawing } \\
\text { during Interval }\end{array}$ & $\begin{array}{c}\text { Number } \\
\text { of OI } \\
\text { cases }\end{array}$ & $\begin{array}{c}\text { Cumulative } \\
\text { Proportion } \\
\text { Surviving } \\
\text { at End of } \\
\text { Interval }\end{array}$ & $\begin{array}{c}\text { Hazard } \\
\text { Rate }\end{array}$ \\
\hline \multirow{5}{*}{ HAART } & {$[0-1)$} & 232 & 34 & 8 & 0.96 & 0.04 \\
\cline { 2 - 8 } & {$[1-2)$} & 190 & 34 & 4 & 0.94 & 0.02 \\
\cline { 2 - 8 } & {$[2-3)$} & 152 & 41 & 5 & 0.90 & 0.04 \\
\cline { 2 - 8 } & {$[3-4)$} & 106 & 53 & 2 & 0.88 & 0.03 \\
\cline { 2 - 8 } & {$[4-5)$} & 51 & 44 & 2 & 0.82 & 0.07 \\
\cline { 2 - 8 } & {$[0-1)$} & 232 & 47 & 88 & 0.58 & 0.53 \\
\cline { 2 - 8 } & {$[1-2)$} & 97 & 22 & 25 & 0.41 & 0.34 \\
\cline { 2 - 8 } & {$[2-3)$} & 50 & 4 & 20 & 0.24 & 0.53 \\
\cline { 2 - 8 } & {$[3-4)$} & 26 & 3 & 16 & 0.08 & 0.97 \\
\cline { 2 - 8 } & {$[4-5)$} & 7 & 0 & 7 & 0.00 & 2.00 \\
\hline
\end{tabular}

Table 3: The actuarial life table estimation of cumulative incidence of Ols in PLWHIV in public Health facilities of Arba Minch town, between November 27, 2009 and January 24, 2014. 
Citation: Misker D, Demissie M, Mellie H (2014) Effect of Highly Active Antiretroviral Therapy on Incidence of Opportunistic Infections among HIV Positive Adults in Public Health Facilities of Arba Minch Town, South Ethiopia: Retrospective Cohort Study. J AIDS Clin Res 5: 330. doi:10.4172/2155-6113.1000330

Page 5 of 6

\begin{tabular}{|c|c|c|c|c|c|}
\hline Covariates & No at risk & No of Ols cases & $\begin{array}{l}\text { Crude Hazard Ratio } \\
(95 \% \mathrm{Cl})\end{array}$ & $\begin{array}{l}\text { Adjusted Hazard Ratio } \\
\qquad(95 \% \mathrm{Cl})\end{array}$ & $P$ value \\
\hline $\begin{array}{l}\text { HAART Status } \\
\text { HAART } \\
\text { Pre-ART } \\
\end{array}$ & $\begin{array}{l}232 \\
232\end{array}$ & $\begin{array}{l}21 \\
156\end{array}$ & $\begin{array}{c}0.06(0.03,0.09) \\
1\end{array}$ & $\begin{array}{c}0.07(0.03,0.16) \\
1\end{array}$ & $<0.001^{*}$ \\
\hline $\begin{array}{l}\text { Sex } \\
\text { Male } \\
\text { Female }\end{array}$ & $\begin{array}{l}167 \\
297\end{array}$ & $\begin{array}{l}91 \\
86\end{array}$ & $\begin{array}{c}1.89(1.41,2.54) \\
1\end{array}$ & $\begin{array}{c}2.19(1.55,3.11) \\
1\end{array}$ & $<0.001^{*}$ \\
\hline $\begin{array}{l}\text { Marital status } \\
\text { Married } \\
\text { Single } \\
\text { Divorced } \\
\text { Widowed } \\
\end{array}$ & $\begin{array}{c}245 \\
58 \\
81 \\
80\end{array}$ & $\begin{array}{l}90 \\
13 \\
43 \\
31\end{array}$ & $\begin{array}{c}1 \\
2.42(1.67,3.51) \\
0.66(0.37,1.18) \\
1.18(0.78,1.78)\end{array}$ & $\begin{array}{c}1 \\
1.45(0.95,2.22) \\
0.86(0.47,1.56) \\
1.68(1.08,2.60)\end{array}$ & $\begin{array}{l}0.083 \\
0.618 \\
0.022^{*}\end{array}$ \\
\hline $\begin{array}{l}\text { Age category } \\
15-24 \\
25-34 \\
35-44 \\
>=45\end{array}$ & $\begin{array}{c}121 \\
177 \\
121 \\
45\end{array}$ & $\begin{array}{c}60 \\
66 \\
43 \\
8\end{array}$ & $\begin{array}{c}1 \\
0.38(0.27,0.55) \\
0.30(0.20,0.46) \\
0.15(0.07,0.31)\end{array}$ & $\begin{array}{c}1 \\
0.44(0.29,0.65) \\
0.27(0.17,0.43) \\
0.18(0.08,0.39)\end{array}$ & $\begin{array}{l}<0.001^{*} \\
<0.001^{*} \\
<0.001^{*}\end{array}$ \\
\hline $\begin{array}{l}\text { Supportive care } \\
\text { Present } \\
\text { Absent }\end{array}$ & $\begin{array}{l}166 \\
298\end{array}$ & $\begin{array}{c}51 \\
126\end{array}$ & $\begin{array}{c}1 \\
1.40(1.01,1.93)\end{array}$ & $\begin{array}{c}1 \\
1.36(0.98,1.89)\end{array}$ & 0.069 \\
\hline $\begin{array}{l}\text { Prophylaxis }{ }^{B} \\
\text { Yes } \\
\text { No }\end{array}$ & $\begin{array}{l}279 \\
185\end{array}$ & $\begin{array}{c}72 \\
105\end{array}$ & $\begin{array}{c}0.19(0.13,0.26) \\
1\end{array}$ & & \\
\hline $\begin{array}{l}\text { Prophylaxis }{ }^{F} \\
\text { Yes } \\
\text { No }\end{array}$ & $\begin{array}{l}193 \\
271\end{array}$ & $\begin{array}{l}86 \\
91\end{array}$ & $\begin{array}{c}1.33(.99,1.79) \\
1\end{array}$ & & \\
\hline $\begin{array}{l}\text { WHO Stage }{ }^{B} \\
\text { Stage I or II } \\
\text { Stage III or IV }\end{array}$ & $\begin{array}{c}389 \\
75\end{array}$ & $\begin{array}{c}164 \\
13\end{array}$ & $\begin{array}{c}1 \\
0.29(0.16,0.50)\end{array}$ & & \\
\hline $\begin{array}{l}\text { Functional Status }{ }^{F} \\
\text { Working } \\
\text { Ambulatory and Bedridden }\end{array}$ & $\begin{array}{c}436 \\
28\end{array}$ & $\begin{array}{c}165 \\
12\end{array}$ & $\begin{array}{c}1 \\
3.33(2.38,4.66)\end{array}$ & & \\
\hline $\begin{array}{l}\text { Address } \\
\text { Urban } \\
\text { Rural }\end{array}$ & $\begin{array}{c}365 \\
99\end{array}$ & $\begin{array}{c}121 \\
56\end{array}$ & $\begin{array}{c}1 \\
1.79(1.30,2.47)\end{array}$ & $\begin{array}{c}1 \\
1.62(1.15,2.27)\end{array}$ & $0.005^{*}$ \\
\hline $\begin{array}{l}\text { Substance use }{ }^{B} \\
\text { Yes } \\
\text { No }\end{array}$ & $\begin{array}{c}82 \\
382\end{array}$ & $\begin{array}{c}45 \\
132\end{array}$ & $\begin{array}{c}2.50(1.78,3.52) \\
1\end{array}$ & $\begin{array}{c}2.11(1.46,3.06) \\
1\end{array}$ & $<0.001^{*}$ \\
\hline $\begin{array}{l}\text { Substance use }{ }^{F} \\
\text { Yes } \\
\text { No }\end{array}$ & $\begin{array}{c}80 \\
384\end{array}$ & $\begin{array}{c}43 \\
134\end{array}$ & $\begin{array}{c}2.21(1.56,3.12) \\
1\end{array}$ & $\begin{array}{c}2.15(1.47,3.13) \\
1\end{array}$ & $<0.001^{*}$ \\
\hline 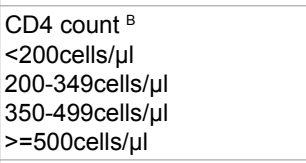 & $\begin{array}{c}33 \\
133 \\
144 \\
154\end{array}$ & $\begin{array}{l}16 \\
64 \\
56 \\
41\end{array}$ & $\begin{array}{c}0.07(.04,0.14) \\
0.09(0.05,0.15) \\
1.04(0.75,1.45) \\
1\end{array}$ & $\begin{array}{c}1.16(0.39,3.58) \\
0.86(0.40,1.84) \\
1.71(1.19,2.46) \\
1\end{array}$ & $\begin{array}{l}0.792 \\
0.694 \\
0.004^{\star}\end{array}$ \\
\hline $\begin{array}{l}\text { CD4 count } F \\
<200 \text { cells } / \mu l \\
200-349 \text { cells } / \mu l \\
350-499 \text { cells } / \mu l \\
>=500 \text { cells } / \mu \mathrm{l}\end{array}$ & $\begin{array}{c}33 \\
133 \\
144 \\
154\end{array}$ & $\begin{array}{l}16 \\
64 \\
56 \\
41\end{array}$ & $\begin{array}{c}3.15(1.75,5.68) \\
2.09(1.40,3.11) \\
1.69(1.12,2.53) \\
1\end{array}$ & $\begin{array}{c}3.36(1.86,6.08) \\
1.71(1.13,2.59) \\
1.72(1.14,2.58) \\
1\end{array}$ & $\begin{array}{c}<0.001^{*} \\
0.011^{*} \\
0.010^{*}\end{array}$ \\
\hline
\end{tabular}

$\mathrm{F}=$ follow up, $\mathrm{B}=$ baseline, ${ }^{*}=\mathrm{P}$-value $<0.05$ is considered as statistically significant

Table 4: Bivariate and multivariate Cox proportional hazard analysis for Predictors of developing Ols among HIV infected patients in public Health facilities of Arba Minch town, 2014.

result from $\mathrm{Co}^{\wedge}$ te d'Ivoire shows higher rate of OIs because of the study includes a wide range of bacterial disease which were not included in this study so which might have overestimated the incidence density rate $[12,13]$.

The incidence of OIs showed a decline from 55.84/100 PY (95\%CI: $47.58,65.13)$ in those patients not using HAART to $3.39 / 100$ PY $(95 \%$ CI: $2.157,5.1)$ in those using HAART. Which is lower than a study conducted in Brazil 113.73/100 PY (95\%CI: 102.24-126.46) in those patients not using HAART to $41.30 / 100$ using HAART. This is due to the study conducted in Brazil includes children but the current study includes only adults.

In the present study, the introduction of HAART is associated with a dramatic effect in the overall reduction of incidence rates of OIs in PLWHIV which is supported by different studies [10,14-17].

In analysis of predictor variable patient with widowed marital status was nearly two times at higher risk of developing OIs than patients with marred marital status. This is possibly because of having supporter for timely taking of medication as directed. Male gender was associated with higher incidence of OIs with $\mathrm{p}<0.001$ which is in congruent with a study by Manosuthi W et al in resource limited settings. 
Citation: Misker D, Demissie M, Mellie H (2014) Effect of Highly Active Antiretroviral Therapy on Incidence of Opportunistic Infections among HIV Positive Adults in Public Health Facilities of Arba Minch Town, South Ethiopia: Retrospective Cohort Study. J AIDS Clin Res 5: 330. doi:10.4172/2155-6113.1000330

Page 6 of 6

Having baseline CD4 count $<200$ and between 200-349 is not associated with occurrence of OIs but CD4 count of between 350-449 was nearly two times higher risk of developing OIs. This may be due to the fact that patients with CD4 count between 350-449 were not taking HAART. Being substance user was more than two times higher risk than non users. This may be due to substance use may cause to take subscribed medications untimely. At follow up patients with CD4 count less than 200 cells/ $\mu$ l; between 200 and 349 cells/ $\mu \mathrm{l}, 350$ and 449 cells/ $\mu \mathrm{l}$ were at increased risk of developing OI than CD4 count of above 500 cells/ $\mu \mathrm{l}$. This is in line with studies conducted by different scholars in different countries $[14,18,19]$. Rural residence increased occurrence of OIs nearly two times than being urban residence. This may be due to the fact that urban residence enables for easy access of information how to prevent occurrence of diseases and treatment purpose.

\section{Conclusions}

During a median of 1.68 PY of follow up OIs were occurred in one third of study participants (38.1\%). The incidence of OIs showed a decline from 55.84/100 PY (95\% CI: 47.58, 65.13) in those patients not using HAART to $3.39 / 100$ PY (95\%CI: $2.157,5.1)$ in those using HAART.

Independent significant predictors that increase occurrence (risk factors) and improve survival (preventive factors) were identified. Those risk factors were being widowed than married, male gender, substance use, rural residence, having baseline CD4 count of 350-499 and follow up CD4 count of other than above 500 cells/ $\mu$ l; however, the preventive factors were taking HAART and not being in age range of 15-24 years. HAART significantly reduced occurrence of OIs so that initiation of HAART even at higher CD4 count has paramount importance.

\section{Recommendations}

To hospitals and health centers with ART clinic (giving HIV care and support)

- Since OI were also common in those with higher CD4 count, PLWHIV should be encouraged to take HAART below 500 cells/ $\mu$ l CD4 count.

- Special consideration should focus on high risk groups such as widowed and substance users.

\section{To Arba Minch town health office and other responsible organizations}

- Health professionals should be encouraged to properly document patients' healthcare data.

\section{To research and academic institutions}

- Further observational studies with prospective design to ascertain the findings are recommended.

\section{References}

1. U.S. (2011) Global Health Policy Fact Sheet the Global HIVIAIDS Epidemic.

2. WHO (2011) Global HIVIAIDS Response: Epidemic update and health sector progress towards Universal Access. WHO, UNICEF UNAIDS.

3. United Nations Programme on HIVIAIDS (UNAIDS); United Nations Development Programme (UNDP) (2009) International consultation on the criminalization of HIV transmission: 31 October-2 November 2007, Geneva, Switzerland. Joint United Nations Programme on HIVIAIDS (UNAIDS) Geneva, United Nations Development Programme (UNDP), New York, 2007. Reprod Health Matters 17: 180-186

4. Central Statistical Agency (CSA) (2011) Ethiopia Demographic and Health
Survey; final draft report. Addis Ababa Ethiopia, ICF International Calverton, Maryland, USA.

5. Federal HIVIAIDS Prevention and Control Office (2010) Annual Performance Report of Multi-sectoral HIV/ AIDS Response.

6. Report on progress towards implementation of the UN Declaration of Commitment on HIVIAIDS. Federal Democratic Republic of Ethiopia Federal HIVIAIDS Prevention and Control Office.

7. Federal ministry of Health (2013) Strategic framework to improve adherence to ART and retention to care in Ethiopia.

8. Mariam ZT, Abebe G, Mulu A (2008) Opportunistic and other intestinal parasitic infections in AIDS patients, HIV seropositive healthy carriers and HIV seronegative individuals in southwest Ethiopia. East Afr J Public Health 5: 169173.

9. Gallant JE, Moore RD, Chaisson RE (1994) Prophylaxis for opportunistic infections in patients with HIV infection. Ann Intern Med 120: 932-944.

10. Candiani TM, Pinto J, Cardoso CA, Carvalho IR, Dias AC, et al. (2007) Impact of highly active antiretroviral therapy (HAART) on the incidence of opportunistic infections, hospitalizations and mortality among children and adolescents living with HIVIAIDS in Belo Horizonte, Minas Gerais State, Brazil. Cad Saude Publica 23: S414-423.

11. Biadgilign S, Reda AA, Digaffe T (2012) Predictors of mortality among HIV infected patients taking antiretroviral treatment in Ethiopia: a retrospective cohort study. AIDS Res Ther 9: 15.

12. Badri M, Ehrlich R, Wood R, Maartens G (2001) Initiating co-trimoxazole prophylaxis in HIV-infected patients in Africa: an evaluation of the provisional WHO/UNAIDS recommendations. AIDS 15: 1143-1148.

13. Anglaret X, Messou E, Ouassa T, Toure S, Dakoury-Dogbo N, et al. (2003) Pattern of bacterial diseases in a cohort of HIV-1 infected adults receiving cotrimoxazole prophylaxis in Abidjan, Côte d'Ivoire. AIDS 17: 575-584.

14. Losina E, Yazdanpanah Y, Deuffic-Burban S, Wang B, Wolf LL, et al. (2007) The independent effect of highly active antiretroviral therapy on severe opportunistic disease incidence and mortality in HIV-infected adults in Côte d'Ivoire. Antivir Ther 12: 543-551.

15. Jerene D, Naess A, Lindtjørn B (2006) Antiretroviral therapy at a district hospital in Ethiopia prevents death and tuberculosis in a cohort of HIV patients. AIDS Res Ther 3: 10.

16. Ghate M, Deshpande S, Tripathy S, Nene M, Gedam P. et al. (2009) Incidence of common opportunistic infections in HIV-infected individuals in Pune, India analysis by stages of immune suppression represented by CD4 counts. Int $\mathrm{J}$ Infect Dis 13: e1-8.

17. Badri M, Wilson D, Wood R (2002) Effect of highly active antiretroviral therapy on incidence of tuberculosis in South Africa: a cohort study. Lancet 359: 2059 2064

18. Misgena KD (2011) The pattern of immunologic and virologic responses to Highly Active Antiretroviral Treatment (HAART): Does success bring further challenges? Ethiop J Health Dev 25: 61-70.

19. Holmes CB, Wood R, Badri M, Zilber S, Wang B, et al. (2006) CD4 decline and incidence of opportunistic infections in Cape Town, South Africa: implications for prophylaxis and treatment. J Acquir Immune Defic Syndr 42: 464-469. 